\title{
Immunodetection of Furcraea Necrotic Streak Virus-FSNV in Fique Plants (Furcraea Macrophylla Baker) Using A Polyclonal Antibody IgY Produced in Chicken Egg Yolk
}

\author{
Deisy Toloza-Moreno \\ Colombian Corporation for Agricultural Research \\ Laura Villamizar-Rivero \\ AgResearch \\ Paola Cuartas-Otálora \\ Colombian Corporation for Agricultural Research \\ Gloria Barrera-Cubillos ( $\sim$ gbarrera@agrosavia.co ) \\ Colombian Corporation for Agricultural Research
}

\section{Research Article}

Keywords: Antibody IgY, DBIA, ELISA, fique, Furcraea necrotic streak virus, macana.

Posted Date: January 15th, 2021

DOI: https://doi.org/10.21203/rs.3.rs-136893/v1

License: (c) This work is licensed under a Creative Commons Attribution 4.0 International License. Read Full License 


\section{Abstract}

The necrotic streak of the fique (Furcraea spp.) or "Macana" disease is considered the most limiting disease for this crop in Colombia, whose causal agent is the Furcraea Necrotic Streak Virus - FSNV (RNA +). Currently, there are no strategies to control the disease, being necessary to develop methods for early detection of this disease in the planting material before being taken to the field. In this study, polyclonal antibodies produced in egg yolk (IgY) were assesses for detection FSNV. Two immunoenzymatic methodologies were standardized: Dot Blot Immunobinding Assay (DBIA) and Enzyme Linked Immunosorbent Assay (ELISA), determining their specificity and sensitivity. The detection limit by DBIA corresponded to $8 \mu \mathrm{g} / \mathrm{mL}$ of purified virus suspension using $10 \mu \mathrm{g} / \mathrm{mL}$ of primary antibody. In the ELISA test, the primary antibody concentration of $3 \mu \mathrm{g} / \mathrm{mL}$ (1:800 dilution) detected the antigen at concentrations between 10 and $70 \mu \mathrm{g} / \mathrm{mL}$. The polyclonal antibody anti-FNSV IgY allowed the detection of FNSV in samples of purified virus and extracts of roots and leaves of fique plants with symptoms of "Macana" disease and did not produce any signal with the control samples. Results showed the potential of using egg yolk IgY for immunological test as a novel approach for the early detection of FNSV in fique plants.

\section{Introduction}

There is an increasing demand for natural fibres worldwide due to their renewable and biodegradable nature and the low cost and low toxic emissions during the recycling processes ${ }^{1}$. The high cost production, difficult recycling and negative environmental impacts of synthetic fibres manufacture, are the main reasons to change the look towards natural fibres ${ }^{2}$. Fique is a "natural fibre" produced by the leaves of the fique plant, Furcraea (Asparagaceae). The genus Furcraea is composed of about 25 species that occur naturally in the Neotropics and naturalized in South Africa, the United States, Portugal, Thailand, India, Australia and the Pacific Islands ${ }^{3}$. Worldwide, several species of Furcraea are cultivated in warm climates as ornamental plants and to obtain fibres from the leaves. Regarding its physiology, it has been reported that Furcraea plants are tolerant to severe water stress due to their ability to recycle carbon dioxide $\left(\mathrm{CO}_{2}\right)$ by CAM metabolism (Crassulacean acid metabolism) and the hard fibres obtained from its leaves are completely biodegradable 4 .

The specie Furcraea macrophyla Baker is predominantly cultivated in the Andean region of Colombia, with $80 \%$ of the production concentrated in the departments of Nariño and Cauca, where smallholders are grouped in regions with low productive agricultural potential ${ }^{5}$. Colombia's industries especially use long-length fibres in ropes and packaging for exporting coffee and cocoa and for manufacturing textiles and handicrafts, reaching about 2.4 million dollars exports in $2018^{5,6}$.

The principal phytosanitary problem of this crop in Colombia is the disease known locally as "Macana" or necrotic streak disease of fique, which dramatically reduces fibre length and quality and can lead the plant to die in advanced infection cases ${ }^{7}$. The causal agent of this disease is the positive RNA virus Furcraea Necrotic Streak Virus (FSNV) (Tombusviridae, Macanavirus) $^{8}$, first reported in the late $1970 \mathrm{~s}^{9,10}$.

FSNV is mainly spread through infected propagation material obtained from asymptomatic plants, problem that could be overcome by testing the vegetative propagation material with a FNSV detection method that allows early eradication of infected plants. The use of immunological tests in the detection, identification and diagnosis of plant pathogens has been of great application in recent years, due to their high reliability, sensitivity and reasonable costs ${ }^{11}$. Currently, several immunological tests are widely used as a diagnostic tool to assess the phytosanitary status of plants, for quarantine purposes or virus certification, and has become an integral part of pathogen indexing ${ }^{12}$. The most widely used immunological tests for this purpose are ELISA method (Enzyme-Linked Immunosorbent Assay) or Enzyme- 
Linked Immunoadsorption Assay and Dot Blot immunobinding assay (DBIA) ${ }^{13}$. However, there is a lack of research on immunological techniques to detect FSNV, being the work of Morales and collaborates $(1992)^{14}$, the only approach available in the literature. Within this work, an immunoenzymatic technique by ELISA was designed to diagnose the disease, achieving detection of the virus only in root tissue of symptomatic plants. Considering the need to develop and implement new high sensitivity techniques to detect the virus in different plant tissues, the objective of this study was to produce polyclonal antibodies specific for the virus and develop diagnostic methodologies capable of detecting FNSV in different tissues of fique plants.

\section{Results}

\section{Viral antigen}

The "Macana" disease symptoms on fique leaves included chlorotic spots, necrotic stripes (Fig. 1A) and breakage of the leaf fibres. The TEM analysis of samples purified from symptomatic material showed viral particles with isometric morphology and average size of $28 \mathrm{~nm}( \pm 2)$ (Fig. 1B).

The electrophoretic analysis (SDS-PAGE) of the purified virus showed four bands corresponding to the proteins described in the viral genome (GenBank FJ768020.1). The capsid protein (UniprotKB D3U5B8_FNSVC) showed an estimated size of $37.1 \mathrm{KDa}$, the polymerase-associated protein showed a band close to 27.3 KDa (UniprotKB D3U5B5_FNSVC) and the movement protein (UniprotKB D3U5B6_FNSVC) showed a band close to $11.8 \mathrm{KDa}$. Additionally, the presence of a fourth low molecular weight protein was evidenced, which corresponds to a second movement protein with a calculated molecular weight of $6.2 \mathrm{KDa}$ (UniprotKB D3U5B7_FNSVC) (Fig. 2).

The sizes of the protein bands are approximate and theoretically calculated using the genome sequence. However, these sizes can vary due to possible post-translational modifications, which can modify the secondary conformation and / or the proteins size. This was evidenced in the electrophoresis gel where an additional band to those previously described was evidenced when the sample was purified and concentrated (Fig. 2, lanes 3 asterisk).

\section{Production of polyclonal antibodies against FNSV}

The polyclonal anti-FNSV IgY antibody was produced by immunizing hens with whole purified virus. The total amount of IgY antibody purified from one egg yolk obtained 20 days post-inoculation was $43.2 \mathrm{mg}$ in $18 \mathrm{~mL}(2.4 \mathrm{mg} / \mathrm{mL})$. The antibody recognized the three main viral proteins (capsid protein, polymerase-associated protein and movement protein) (Fig. 2). Additionally, the antibody recognized another band with an estimated size of $32 \mathrm{KDa}$ (Fig. 2, asterisk in lane 4), which may correspond to a viral protein with post-translational changes. A very faint band was detected by the anti-FNSV that corresponds to the size estimated for predicted protein of ORF 2 (UniprotKB D3U5B4_FNSVC), a readthrough of ORF 1, which correspond with an 87 KDa RNA-directed RNA polymerase (Fig. 2, dagger in lane 4).

\section{DBIA}

The minimum antigen concentration that was detected with the anti-FNSV using the DBIA technique was $8 \mu \mathrm{g} / \mathrm{mL}$ of purified virus, by using $10 \mu \mathrm{g} / \mathrm{mL}$ of primary antibody (Fig. 3). The anti-FNSV IgY antibody also showed affinity for the virus present in leaves and root macerates of fique seedlings previously determined as positive for viral infection by RTPCR. All samples showed positive staining in the DBIA test after the application of the specific chromogen for alkaline phosphatase. However, the positive signals obtained with some foliar samples (Fig. 4A, columns 5-9) were clearer than those obtained with samples of roots obtained from the same plants (Fig. 4B, columns 3-9), which could suggest 
a higher concentration of virus particles per gram of tissue in the root extracts. Foliar samples of healthy plants did not produce a positive signal (staining) on the membrane (Fig. 4C).

On the other hand, the anti-FNSV IgY antibody showed specificity for the "Macana" virus and was not able to recognize the other RNA viruses assessed with the DBIA test. Viruses different from FNSV were in samples of foliar material infected with RMVc (associated symptoms possibly to the complex of Rose Mosaic Virus) and PYVV (Potato Yellow Vein Virus), for which, no signal was detected on the nitrocellulose membrane (same colour before and after development), when compared with the positive control (Fig. 5, columns 2 and 6) that produced purple coloration after development with alkaline phosphatase (Fig. 5).

\section{ELISA}

Three dilutions of the anti-FNSV IgY antibody (1:400, 1:800 and 1:1600) were evaluated with the ELISA technique against different concentrations of viral antigen. Following the method proposed by Parola and collaborates $(2003)^{15}$, the cut-off point of the test was determined (absorbance of 0.2746 ), which corresponded to two standard deviations above the mean of the negative controls (control 1: primary antibody IgY plus secondary antibody and control 2: PBS; each consisting of seven replicates for a total of 14 replicates for the assay). The correlation coefficient was 0.7364 for the 1:1600 primary antibody dilution, in which the highest absorbance obtained (for antigen concentration $70 \mu \mathrm{g} / \mathrm{mL}$ ) was lower than that reached with the other two primary antibody dilutions (OD: 0.3261, Fig. 6A). Although the correlation coefficients were very similar for the $1: 400$ and 1:800 antibody dilutions ( $r^{2}: 0.9469$ and 0.9324 , respectively), the 1:800 dilution was determined as the $\mathrm{lgY}$ antibody titer $(3.013 \mu \mathrm{g} / \mathrm{mL})$ for producing absorbances significantly above the cut-off point $(P<0.05)$ (Fig. 6A).

The sensitivity analysis of the ELISA test using this antibody dilution, allowed to establish the minimum and maximum limit of viral detection in $10 \mu \mathrm{g} / \mathrm{mL}$ and $70 \mu \mathrm{g} / \mathrm{mL}$, respectively. In this context, the residual plot analysis (Fig. 6B) showed scatter points with a random pattern on either side of the zero value when different concentrations of antigen were evaluated against the three dilutions of IgY antibody, which is explained by the standard error lower than 0.02 , which indicates an adequate adjustment of data to a linear model.

The viral titres in the macerates from leaves and roots of diseased plants were calculated based on the extrapolation in the linear regression line of the pure virus. The viral concentration estimated for the leaf samples decreased as the concentration of anti-FNSV IgY decreased, with values of $317.37 \mu \mathrm{g} / \mathrm{mL}$ for the $1: 400$ dilution of $\mathrm{IgY}$, of $276.95 \mu \mathrm{g} / \mathrm{mL}$ for $1: 800$ and of $133.95 \mu \mathrm{g} / \mathrm{mL}$ for $1: 1600$, while the viral presence was not detected in the roots, with any of the three dilutions of the primary antibody.

\section{Discussion}

Fique is a crop of great social importance in Colombia, considering that it is the base of the economy for many families of farmers and indigenous communities. This crop is produced in marginal areas, with steep slopes and physically and chemically degraded soils. Among the phytosanitary problems, the "Macana" disease is the most limiting, being distributed in various fique-producing areas withing the country and causing economic losses close to $30 \%{ }^{16}$. The damage caused by the disease is devastating in severe cases, where death is inevitable and considering that a plant must grow three years after its plantation to reach its productive age. So far there is no treatment to control this disease, being prevention the most efficient tool to reduce its economic and social impact. In this context, there is a need of diagnostic techniques able to determine if the planting material is virus free, before being sown to the field. In the present study, a polyclonal antibody anti-FNSV IgY able to be used with samples of leaves and roots of fique plants 
was produced in chicken eggs. Antibodies produced in egg yolk have been widely used for the recognition of specific peptides and proteins of various organisms including plant pathogenic viruses $17,18,19,20$.

Its production increases from the first week after the hens are inoculated ${ }^{21}$, but the specificity of purified IgY antibodies occurs from the second week ${ }^{22}$ and can remain after long post-inoculation periods. The antigen used in this work corresponded to purified virus obtained from the leaves of diseased plants, which showed isometric morphology similar to that reported by Morales and collaborators $(1992)^{14}$, who first described the virus causing the disease in the department of Cauca (Colombia). The diameter of the viral particles observed in the present work was lower than that previously reported, which is possibly related with differences in the staining methodology or the equipment calibration. Additionally, there may be morphological and genetic variations related to the geographical distribution of this disease within the different regions of the country.

Polyclonal antibody production in chickens has proven to be a worthwhile alternative to conventional antibody production in mammals, because the animal care costs are low and eliminates the pain caused by invasive blood sampling, while a laying hen produces more yolk antibodies than a small mammal can produce during the same time period $^{23,24,25}$. The "Macana" disease is a local problem, reason why, antibodies for disease diagnostic are not commercially available. Therefore, the production of anti-FNSV IgY in chickens represents an easy and accessible method, taking into account that previous study reported the production of anti-FNSV antibodies in rabbits, which recognized viral particles in samples of roots of infected plants, however it did not recognize the viral particles present in leaves of the same plants ${ }^{14}$.

The anti-FNSV IgY produced in this work recognized the main proteins of the FNSV, the majority corresponding to the capsid protein, the polymerase-associated protein and one of the movement proteins. Additionally, the anti-FNSV IgY recognized a fourth protein, whose molecular weight suggests that it could correspond to the polymerase-associated protein with post-translational changes that modify its folding and migration on electrophoresis. Post-translational modifications such as ubiquitination and phosphorylation have been reported in viral replicases and allow the regulation of their functions ${ }^{26,27}$.

The detection limit obtained for the anti-FNSV IgY using the DBIA technique was lower than those determined for other antibodies produced in other species to recognize phytopathogenic viruses, even using higher antibody dilutions ${ }^{28,29,30}$. On the other hand, the anti-FNSV IgY titre obtained through the ELISA technique in the present study was higher than those reported in similar works with IgY and sandwich-type ELISA ${ }^{20}$, where two targeted antibodies against antigen were used to ensure detection with lower concentrations of antibody.

In general, immunological techniques are an excellent alternative to molecular tests such as RT-PCR, where the purification of nucleic acids is required. There is an advantage in the detection techniques presented in this work, which allowed the use of only one secondary commercial antibody. This strategy avoids the necessity of making specific enzyme conjugates, which makes it very interesting for the development of detection methods for other plant viruses by using different primary antibodies ${ }^{11}$. Here, we present an interesting alternative to produce primary antibodies directed against viruses that cause very local diseases with little global commercial interest.

The detection of phytopathogenic viruses in different plant tissues depends on the infection process. FNSV enters to the roots throughout vector fungi, then viral replication process occurs in the leaf tissue and thanks to the viral movement proteins, the infection gets systemic ${ }^{31}$. In this work, viral detection was carried out in root and leaf tissue of diseased plants using the DBIA technique but detection in roots was not possible using the ELISA technique, like those results reported with antigens from other phytopathogens ${ }^{32}$. Since the reactivity of anti-FNSV IgY was demonstrated 
using pure virus and foliar material, the negative result obtained with roots could possibly be related to an inhibitor present in the fique roots, which could interfere with the adsorption of the antigens to the reaction surface. This interference should be addressed by improving the methodology for preparation of plant material samples.

Although the use of the indirect ELISA technique to quantify the antigen present in the sample through a standard curve was demonstrated, DBIA has great advantages such as lower cost, no need for special laboratory equipment, shorter processing time and detection in very small sample volume $(2 \mu \mathrm{L})$ compared with ELISA $(100 \mu \mathrm{L})$. Additionally, nitrocellulose did not present interference to acquire the antigen from different tissues plant.

\section{Materials And Methods}

\section{Statement}

All experiments and methods were performed in accordance with relevant guidelines and regulations. All experimental protocols were approved by the Ad Hoc Bioethics Committee of AGROSAVIA integrated by scientists with training and experience in Animal Health and Wellbeing, one delegate from Instituto Colombiano Agropecuario (ICA), one delegate from the Colombian Environmental Authority and one delegate from the Colombian Society for Animal Protection. The Bioethics Committee approved by an informed consent, all subjects of the present research and all methods were carried out in accordance with the relevant guidelines and Colombian regulations (Law 84/89 and Res 8430/93 for biomedical research using animals). The study was carried out in compliance with the ARRIVE guidelines.

\section{Sources of virus and plant material}

For virus purification, leaves of the fique plants, Furcraea macrophylla Baker ${ }^{6}$, that presented the common symptomatology of the necrotic streak disease of fique "Macana", were collected in the municipality of El Tambo, department of Nariño, Colombia, located over 2000 meters above sea level. Methodologies were validated with samples of roots and leaves from fique plants with and without symptoms of infection but previously determined positive by RT-PCR based on movement protein for FNSV presence ${ }^{33}$ (data not shown). Leaves of healthy plants negative by RT-PCR were also analyzed and used as negative controls.

The plant material used to asses antibodies specificity corresponded to vegetal tissue of rose (Rosa sp.) exhibiting symptoms of viral infection possibly related to the Rose mosaic virus complex (RMVc), and vegetal tissue of potato (Solanum tuberosum) with Potato yellow vein virus (PYVV).

\section{Antigen preparation}

Viral semi-purification was performed using the methodology described by Morales and collaborators (1992) ${ }^{14}$ with modifications, as follows: the symptomatic leaf material $(250 \mathrm{~g})$ was cut into $2 \mathrm{~cm}^{2}$ pieces that were liquefied in 230 $\mathrm{mL}$ of $0.01 \mathrm{M}$ EDTA buffer solution $(\mathrm{pH} 7.8)$ and $1 \%$ beta-mercaptoethanol $(1: 1 \mathrm{w} / \mathrm{v})$. The extract was filtered and centrifuged at $7000 \mathrm{rpm}$ for $15 \mathrm{~min}$ at $4{ }^{\circ} \mathrm{C}$. The supernatant was incubated at $55^{\circ} \mathrm{C}$ for $10 \mathrm{~min}$, then centrifuged at $8800 \mathrm{rpm}$ for $15 \mathrm{~min}$ and stored at $4{ }^{\circ} \mathrm{C}$ overnight. For complete purification, the sample was centrifuged at $24000 \mathrm{rpm}$ for $3 \mathrm{~h}$ and the pellet was suspended in 0.01M EDTA buffer with 1\% beta-mercaptoethanol (1:1 w/v) to be centrifuged at $10000 \mathrm{rpm}$ for $15 \mathrm{~min}$ and the supernatant was recovered and placed on a discontinuous sucrose gradient (10-40\%), which was centrifuged at $18000 \mathrm{rpm}$ for $4 \mathrm{~h}$. The formed band was taken by lateral puncture of the tube and mixed with $0.01 \mathrm{M}$ EDTA buffer $(1: 10 \mathrm{v} / \mathrm{v})$. Finally, the sample was centrifuged at $30000 \mathrm{rpm}$ for $1 \mathrm{~h}$ and the pellet was suspended with $0.01 \mathrm{M}$ EDTA buffer $(1: 1 \mathrm{w} / \mathrm{v})$ and storage at $-20^{\circ} \mathrm{C}$.

\section{Transmission electron microscopy}


A morphological analysis of the purified virus samples was performed using transmission electron microscopy (TEM). The viral sample was applied to the top of 300 mesh copper grids covered with a FOMVAR film. After 15 min, the grids were negative stained with $1 \%$ phosphotungstic acid $(\mathrm{pH} \mathrm{6.5)}$ for $15 \mathrm{~min}$. and observed in transmission electron microscope (Jeol 1400 plus).

\section{Sodium Dodecyl Sulfate Polyacrylamide Gel Electrophoresis}

The viral proteins were characterized by Sodium Dodecyl Sulfate Polyacrylamide Gel Electrophoresis (SDS-PAGE) using a $12 \%$ separating gel and a $3 \%$ concentrating gel. The semi-purified virus and purified virus was mixed with loading buffer (125mM Tris-HCl, 2\% SDS, pH 6.2, 10\% glycerol, 0.004\% bromophenol blue, and 5\% 2-mercaptoethanol) and heated at $100{ }^{\circ} \mathrm{C}$ for $5 \mathrm{~min}$. Proteins were separated in an electrophoresis chamber (Mini-PROTEAN ${ }^{\circledR}$ Bio-Rad) for 180 min at $80 \mathrm{~V}$. The gel was stained with Coomassie brilliant blue $(0.1 \%)$ for $30 \mathrm{~min}$, discolored for $1 \mathrm{~h}$ and visualized on an image analyzer (Chemi-DocBioRad, California, USA). Protein weight was estimated using a molecular weight marker (Invitrogen, Cat. No. 10747-012) as reference.

\section{Production of polyclonal antibodies}

Polyclonal antibody (anti-FNSV) was produced in 18-week-old Babcock Brown hens, which were inoculated with purified viral particles using a three-application scheme at 10-day intervals. The first injection was made intramuscularly with $190 \mu \mathrm{g}$ of virus mixed with complete Freund's adjuvant (SIGMA $\left.{ }^{\circledR}\right)$. For the following two immunizations, $95 \mu \mathrm{g}$ of virus mixed with incomplete adjuvant $\left(\right.$ SIGMA $\left.^{\circledR}\right)$ were used. All the eggs were harvested and stored in a refrigerator at $4{ }^{\circ} \mathrm{C}$. The egg collected 20 days after the last inoculation was cracked, and the egg white was separated from the yolk. The yolk sac was ruptured with a needle and the content was dripped into a tared beaker. After discarding the yolk sac, the weight of the separated yolk was measured. Immunoglobulins Y (IgY) was extracted from the egg yolk by using the commercial IgY EGGstract IgY Purification System Kit (Promega Cat. No. G2610). Then, the precipitated IgYs were dissolved in PBS and stored at $-20^{\circ} \mathrm{C}$ until analysis.

\section{Western Blot Immunodetection}

Viral proteins from pure virus were separated on SDS-PAGE $12 \% \mathrm{gel}$ and run at $100 \mathrm{~V}$ for $180 \mathrm{~min}$. The separated proteins were electro-transfered onto nitrocellulose membranes and blocked with $5 \%$ skim milk. These strips were incubated with purified anti-FNSV at $3 \mu \mathrm{g} / \mathrm{mL}$ (1:800 dilution) and anti-Chicken IgY (IgG) (whole molecule)-Alkaline Phosphatase produced in rabbit (SIGMA Cat. No. A9171) (1:5000 dilution). Bands were made visible on the membrane using 5-bromo-4-chloro-3-indolyl-phosphate / nitro blue tetrazolium (BCIP / NBT Color Development Substrate-SIGMA FAST Cat. No. B5655).

\section{Immunological tests}

For immunological tests, pure virus was used as positive control and the samples included foliar and root macerates from fique plants. To determine the anti-FNSV detection limit, serial dilutions of pure virus were used as antigen for DBIA and indirect ELISA techniques.

\section{Foliar and root macerates preparation}

To obtain the foliar and root macerates for immunological tests, the plant tissue was cut in small pieces $\left(5 \mathrm{~mm}^{2}\right)$ and macerated with liquid nitrogen. Then, 0.01M EDTA buffer $(\mathrm{pH} 7.8)$ was added to $3.5 \mathrm{~g}$ of macerate $(1: 1 \mathrm{w} / \mathrm{v})$. The sample was mixed and centrifuged at $7700 \mathrm{~g}$ for $15 \mathrm{~min}$ at $4{ }^{\circ} \mathrm{C}$. The supernatant was removed, incubated at $55^{\circ} \mathrm{C}$ for 
$10 \mathrm{~min}$ and centrifuged at $12000 \mathrm{~g}$ for $15 \mathrm{~min}$ at $4{ }^{\circ} \mathrm{C}$. Finally, the supernatant was used directly for DBIA test and mixed with $100 \mathrm{mM}$ Phosphate-Buffered Saline (1:1 w/v) for ELISA test.

\section{Dot Blot Immunobinding Assay (DBIA)}

The viral suspension was diluted from 22000 to $3 \mu \mathrm{g} / \mathrm{mL}$ and used as antigen for the DBIA test. Additionally, foliar and roots macerates from fique seedlings were used to validate the methodology, including healthy and diseased plants. Foliar macerates of rosa (Rosa sp.) and potato (Solanum tuberosum) mentioned before were tested to determine specificity.

Aliquots of $2 \mu \mathrm{L}$ of antigen were spotted onto a nitrocellulose membrane by triplicate and allowed to dry overnight at 4 ${ }^{\circ} \mathrm{C}$. The membrane was washed once in washing solution (Tris- $\mathrm{HCl} 1 \mathrm{~mol} / \mathrm{L} \mathrm{10 \% ,} \mathrm{EDTA} \mathrm{0.2 \% ,} \mathrm{Tween} 200.1 \%, \mathrm{NaCl}$ 0.9\%) with gentle agitation for 2 min, then covered with blocking buffer (PBS 100 mM, Tween 20 0.05\%, non-fat dry milk 5\%) and incubated for $2 \mathrm{~h}$ at $37^{\circ} \mathrm{C}$ and $27 \mathrm{rpm}$. The membrane was then washed three times and $20 \mu \mathrm{L}$ of antiFNSV ( $\mathrm{lgY})(10 \mu \mathrm{g} / \mathrm{mL})$ was added onto each dot of pre-immobilized antigen followed by $1 \mathrm{~h}$ incubation at $37^{\circ} \mathrm{C}$ and $27 \mathrm{rpm}$. After washing three times, the membrane was three times, it was covered with blocking buffer and incubated for $30 \mathrm{~min}$ at $37^{\circ} \mathrm{C}$ and $27 \mathrm{rpm}$. The membrane was washed two times, and alkaline phosphatase (AP)-conjugated rabbit anti-Chicken IgY (IgG) (SIGMA Cat. No. A9171) (1:5000 dilution) was added covering the entire membrane, incubating for $1 \mathrm{~h}$ at $37^{\circ} \mathrm{C}$ and $27 \mathrm{rpm}$. Finally, the membrane was washed three more times (5 min / each wash), and the BCIP / NBT color development substrate for nitrocellulose membranes was used to cover the membrane, leaving for $15 \mathrm{~min}$ at room temperature. The membrane was washed with ultrapure water and allowed to dry at room temperature.

\section{Enzyme-linked Immunosorbent Assay (ELISA)}

An indirect ELISA test was performed to assess the antibody sensitivity using different dilutions of pure virus (from 10 to $70 \mu \mathrm{g} / \mathrm{mL}$ ). Foliar and root macerates from fique plants with symptoms of FSNV infection were also analyzed.

All reagents were added to wells of Nunc MaxiSorp ${ }^{\circledR}$ flat-bottom microplates (Thermo Scientific ${ }^{\mathrm{TM}}$ ) in $100 \mu \mathrm{L}$ volumes. The antigens were first added and adsorbed overnight at $4{ }^{\circ} \mathrm{C}$. The microplate was washed three times with PBS-T (PBS 100 mM, Tween 20 0.05\%), covered with blocking buffer (non-fat dry milk 5\% in PBS-T), and incubated for $1 \mathrm{~h}$ at $37^{\circ} \mathrm{C}$ and $27 \mathrm{rpm}$. After washing three times with PBS-T, the anti-FNSV was added to each well and incubated for $1 \mathrm{~h}$ and $30 \mathrm{~min}$ at $37^{\circ} \mathrm{C}$ and $27 \mathrm{rpm}$. The plate was again washed three times and followed by addition of alkaline phosphatase (AP)-conjugated rabbit anti-Chicken IgY (IgG) (SIGMA Cat. No. A9171) diluted 1:1000 (1.5 h, $37^{\circ} \mathrm{C}, 27$ $\mathrm{rpm}$ ). Finally, the plate was washed three times and the substrate to detect alkaline phosphatase activity (p-nitrophenyl phosphate (pNPP), Sera Care Cat. No. 5120-0056) was added. The plate was then incubated at room temperature for 1 $\mathrm{h}$ in darkness and the reaction was stopped by adding 5\% EDTA solution. The absorbances were read on a plate reader at $405 \mathrm{~nm}$. Positive reactions were considered those in which the absorbance readings presented a value greater than three times the reading obtained in the negative control, according to the criterion of Matthews $(1993)^{34}$.

\section{Statistical analysis}

The results obtained with indirect ELISA were evaluated through a simple lineal regression using GraphPad Prism version 8.00 for WINDOWS ${ }^{\circledR}$ (GraphPad Software, San Diego, CA) ${ }^{35}$ and the legitimacy of the model was tested by a residual plot analysis.

\section{Declarations}

\section{Aknowledgements}


We are grateful to the Corporación Colombiana de Investigación Agropecuaria (AGROSAVIA) for providing physical and human resources. This work was supported by grants from the Colombian Ministry of Agriculture and Rural Development (MADR). The authors thank Dr. Sadao Kobayashi (AGROSAVIA's Tibaitatá Research Centre).

\section{Conflicts of interest}

The authors declare that there are no conflicts of interest.

\section{References}

1. Sadrmanesh, V. \& Chen, Y. Bast fibres: structure, processing, properties, and applications. Int. Mater. Rev. 1-26 https://doi.org/10.1080/09506608.2018.1501171 (2018).

2. Terzopoulou, Z. et al. Green composites prepared from aliphatic polyesters and bast fibers. Ind. Crop. Prod. 68, 6079 https://doi.org/10.1016/j.indcrop.2014.08.034 (2015).

3. Murillo, J., Barón, E. \& Alzate, F. Anatomía foliar comparativa de tres especies de Furcraea (Asparagaceae: Agavoideae). Hoehnea. 45, 607-615. https://doi.org/10.1590/2236-8906-06/2018 (2018).

4. Casierra-Posada, F. \& González, D. Cambio circadiano de pH y acidez titulable en la savia de fique (Furcraea castilla y F. macrophylla). Orinoquia. 13 (1), 5-13 (2009).

5. Ministerio de Agricultura y Desarrollo Rural. Cadena Agroindustrial del Fique. Dirección de Cadenas Agrícolas y Forestales. 2019. Available at: https://sioc.minagricultura.gov.co/Fique/Documentos/2019-0630\%20Cifras\%20Sectoriales.pdf [Accessed: 23 July 2020].

6. Kozlowski, R., Mackiewicz-Talarczyk, M. \& Barriga-Bedoya, J. New emerging natural fibres and relevant sources of information. In: Kozlowski, R. \& Mackiewicz-Talarczyk, M. (Eds.). Handbook of natural fibers. Woodhead Publishing, pp. 747-787(2020).

7. Peinado, J. E. et al. Guía ambiental del subsector fiquero 2006. Available at: http://bibliotecadigital.agronet.gov.co/bitstream/11348/6697/1/2007222154336_GuiaAmbientalFiquera2006.pdf. [Accessed: 1 July 2017].

8. Adams, M. J., King, A. M. Q. \& Carstens, E. B. Ratification vote on taxonomic proposals to the International Committee on Taxonomy of Viruses. Arch Virol. 158, 2023-2030 https://doi.org/10.1007/s00705-013-1688-5 (2013).

9. Dabek, A. J. \& Castano, J. J. The occurrence, symptomatology, transmission and virus aetiology of macana disease of fique (Furcraea spp.) in Colombia, South America. J Phytopathol. 92, 57-69 https://doi.org/10.1111/j.1439-0434.1978.tb03584.x (1978).

10. Castaño, M. \& Morales, F. Detección inmunoenzimática del virus de la macana del fique (Furcraea spp.). Fitopatología Colombiana. 14, 29-31 (1990).

11. Abd El-Aziz, M. H. Three modern serological methods to detect plant viruses. J Plant Sci Phytopathol. 3, 101-106 https://doi.org/10.29328/journal.jpsp.1001039 (2019).

12. Boonham, N. et al. Methods in virus diagnostics: From ELISA to next generation sequencing. Virus Res. 186, 20-31 https://doi.org/10.1016/j.virusres.2013.12.007 (2014).

13. Webster, C. G., Wylie, S. J. \& Jones, M. G. Diagnosis of plant viral pathogens. Curr. Sci. 8612, 1604-1607 (2004).

14. Morales, F., Castaño, M., Calvert, L. \& Arroyave, J. Furcraea Necrotic Streak Virus: An Apparent New Member of the Dianthovirus Group. J Phytopathol. 134, 247-254 https://doi.org/10.1111/j.1439-0434.1992.tb01233.x (1992).

15. Parola, D. A., Sciocco-cap, A., Glikmann, G. \& Romanowski, V. An immunochemical method for quantitation of Epinotia aporema granulovirus (EpapGV). J Virol Methods. 112, 13-21 https://doi.org/10.1016/S0166- 
0934(03)00185-X (2003).

16. Flórez, R., Beltrán-Acosta, C. \& Toro, I. Análisis económico e impacto del virus de la macana en el cultivo de fique. In: Smith, A., Beltrán-Acosta, C. \& Cotes, A.M. (Eds.). Avances en el estudio del virus de la macana en el cultivo de fique (Furcraea spp.). Mosquera: Corpoica. pp. 21-29(2013).

17. Van Regenmortel, M. H. V. \& Burckard, J. Detection of a wide spectrum of tobacco mosaic virus strains by indirect enzyme-linked immunosorbent assays (ELISA). Virology. 106, 327-334 https://doi.org/10.1016/00426822(80)90256-1 (1980).

18. Wechmar, M. B., Kaufmann, A., Desmarais, F. \& Rybicki, E. P. Detection of Seed-Transmitted Brome Mosaic Virus by ELISA, Radial Immunodiffusion and Immunoelectroblotting Tests. J Phytopathol. 1094, 341-352 https://doi.org/10.1111/j.1439-0434.1984.tb00728.x (1984).

19. Melzer, M. J., Sether, D. M., Borth, W. B. \& Hu, J. S. Characterization of a virus infecting Citrus volkameriana with citrus leprosis-like symptoms. Phytopathology. 1021, 122-127 https://doi.org/10.1094/phyto-01-11-0013 (2012).

20. Sijam, K. \& Sulaiman, I. Production of polyclonal antibody to the coat protein of Citrus Tristeza virus in chicken eggs. Indones. J. Agric. Sci. 41, 18-26 https://doi.org/10.21082/ijas.v4n1.2003.p18-26 (2013).

21. Gordon, G. et al. Generation and characterization of IgY antibodies from Lohmann Brown hens immunized with Salmonella spp. for their subsequent application in nanotherapy. Biology and Medicine. 8, 1-6 (2016).

22. Sunwoo, H. H., Nakano, T., Dixon, W. T. \& Sim, J. S. Immune responses in chickens against lipopolysaccharide of Escherichia coli and Salmonella typhimurium. Poult Sci. 753, 342-345 https://doi.org/10.3382/ps.0750342 (1996).

23. Hodek, P., Trefil, P., Simunek, J., Hudecek, J. \& Stiborova, M. Optimized Protocol of Chicken Antibody (IgY) Purification Providing Electrophoretically Homogenous Preparations. Int. J. Electrochem. Sci. 8, 113-124 (2013).

24. Blanco-Carrero, C., Díaz, M., Figuera, D., Palacios, A. \& Araujo, Z. Aplicaciones experimentales de la inmunoglobulina Y. Su utilidad en diagnóstico. Acta Cient Estud. 9, 22-34 (2014).

25. Amro, W. A., Al-Qaisi, W. \& Al-Razem, F. Production and purification of IgY antibodies from chicken egg yolk. J Genet Eng Biotechnol. 16, 99-103 https://doi.org/10.1016/j.jgeb.2017.10.003 (2018).

26. Hericourt, F., Blanc, S., Redeker, V. \& Jupin, I. Evidence for phosphorylation and ubiquitinylation of the turnip yellow mosaic virus RNA-dependent RNA polymerase domain expressed in a baculovirus-insect cell system. Biochem J. 349 (Pt 2), 417-425 (2000). https://dx.doi.org/10.1042\%2F0264-6021\%3A3490417

27. Jakubiec, A. \& Jupin, I. Regulation of positive-strand RNA virus replication: The emerging role of phosphorylation. Virus Res. 129, 73-79 https://doi.org/10.1016/j.virusres.2007.07.012 (2007).

28. Hu, J. S., Li, H. P., Barry, K., Wang, M. \& Jordan, R. Comparison of dot blot, ELISA, and RT-PCR assays for detection of two cucumber mosaic virus isolates infecting banana in Hawaii. Plant Dis. 799, 902-906 https://doi.org/10.1094/PD-79-0902 (1995).

29. Iracheta, M. M., Arrieta, L. D. C. \& Rocha, M. A. Detección del virus tristeza de los cítricos mediante anticuerpos contra la proteína recombinante p25 de la cápside bajo un sistema de inmunoimpresión. Rev Mex Fitopatol. 301, 31-42 (2012).

30. Sum, M. S. H., Yee, S. F., Eng, L., Poili, E. \& Lamdin, J. Development of an Indirect ELISA and Dot-Blot Assay for Serological Detection of Rice Tungro Disease. BioMed Res Int. 1-7 https://doi.org/10.1155/2017/3608042 (2017).

31. Rochon, D. Molecular insights into plant virus-vector interactions. In: Punja, Z., De Boer, S. \& Sanfacon, H. (Eds.) Biotechnology and Plant Disease Management.CAB International, Wallingford, U.K.pp. 532-567. (2007)

32. Álvarez, J., Cotes, J. \& Marín, M. Detección molecular de virus en material de siembra de tomate de árbol en Colombia. Rev Protección Veg. 26 (2), 80-91 (2011). 
33. Barrera, G. \& Belaich, M. Descripción morfológica y molecular de un aislamiento colombiano del virus de la raya necrótica del fique. 2015. In: XI Congreso Argentino de Virología y II Congreso Latinoamericano de Virología, 2326 June 2015, Ciudad Autónoma de Buenos Aires, Argentina.

34. Matthews, R. E. F. Diagnosis of plant virus diseases (CRC Press, Boca Ratón, 1993).

35. GraphPad Prism version 8.0.0 for Windows, GraphPad Software, San Diego, California USA. Available at: http://www.graphpad.com. [Accessed 1 June 2020].

\section{Figures}

A

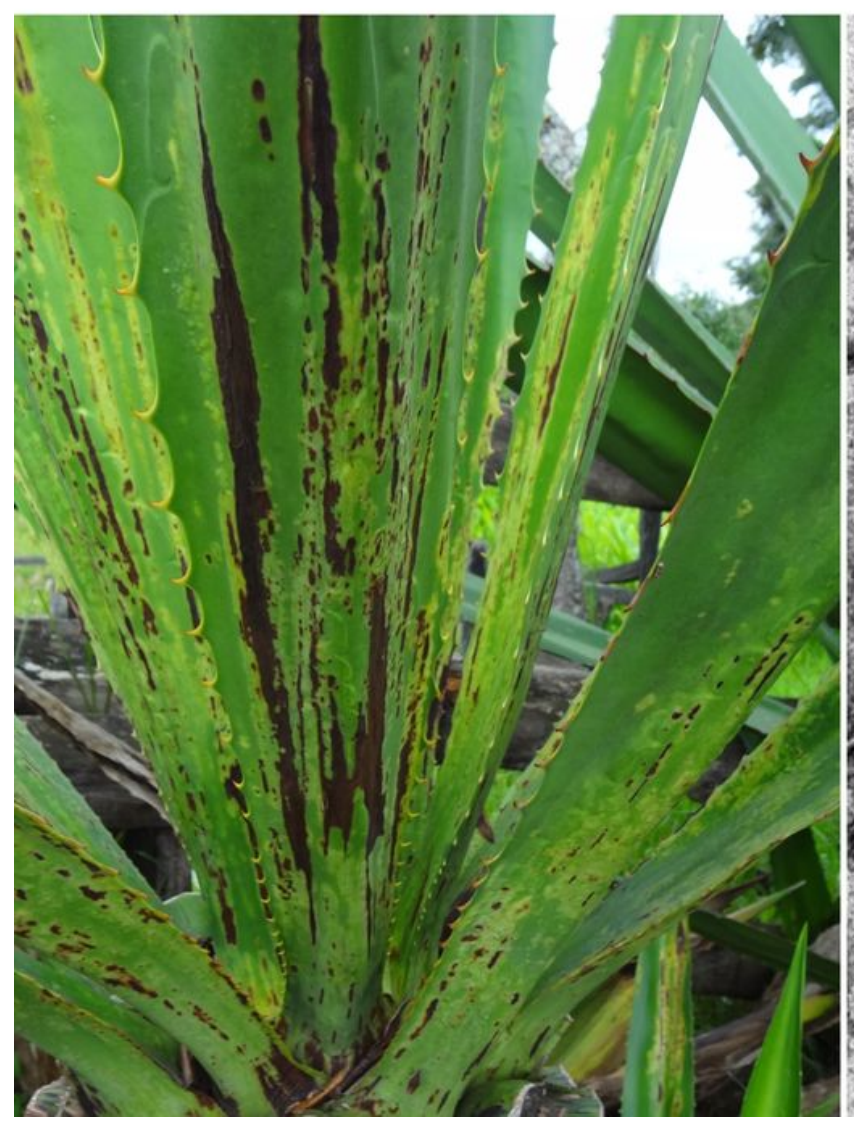

B

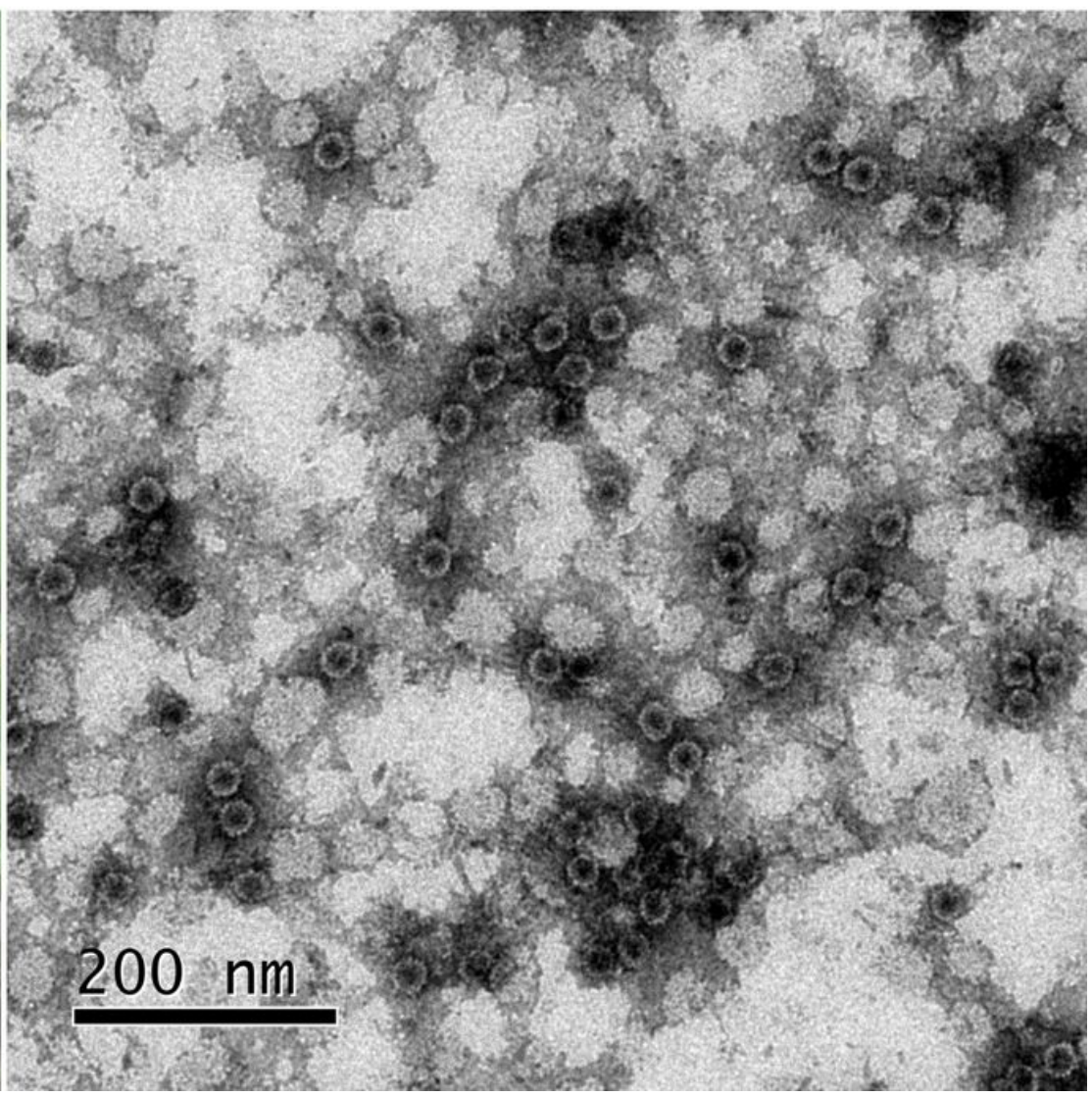

\section{Figure 1}

A) Fique leaves with typical symptoms of "Macana" disease. B) Electron micrograph of FNSV particles purified by ultracentrifugation and stained with phosphotungstic acid. 


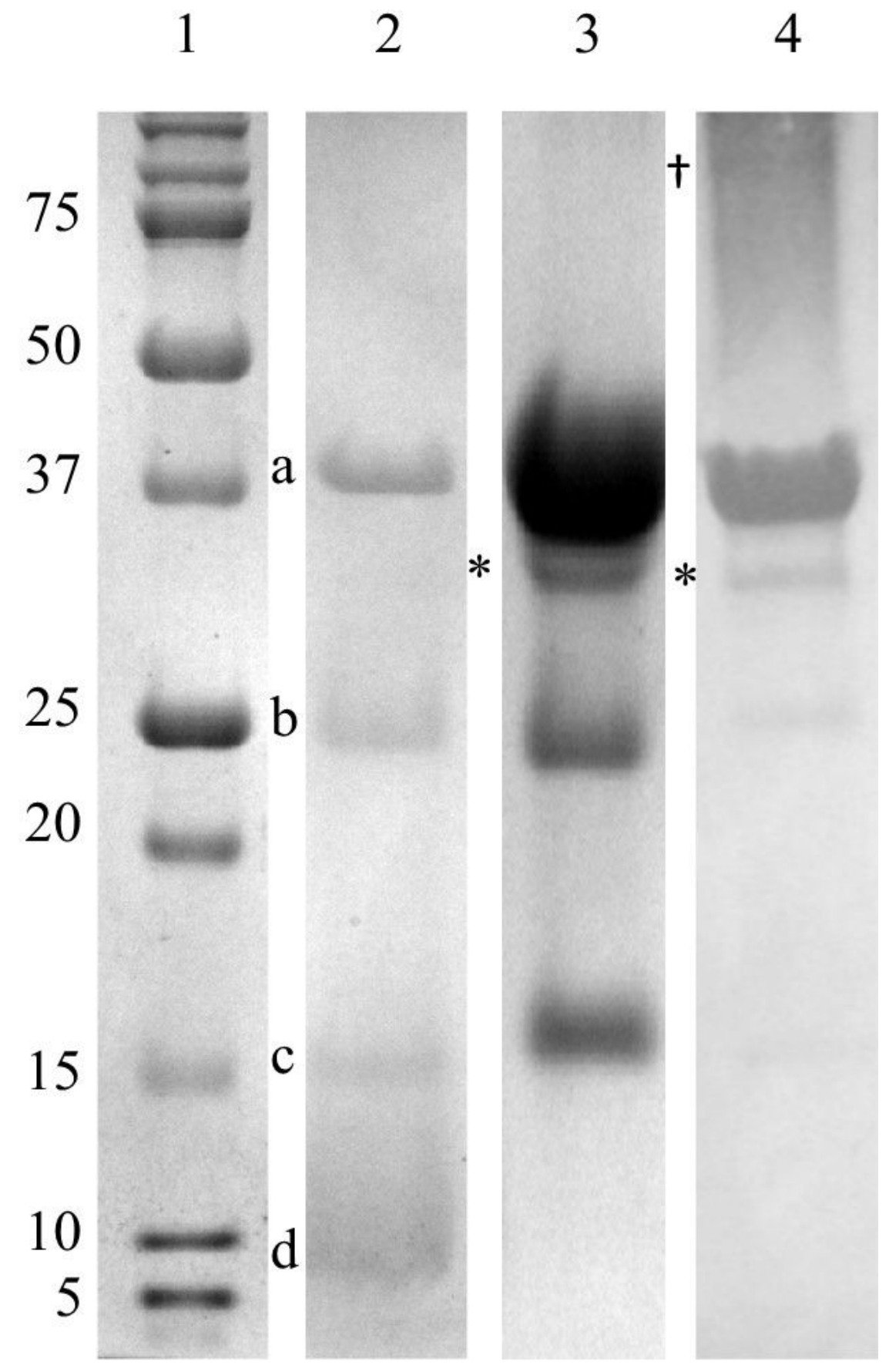

Figure 2

Protein electrophoresis SDS-PAGE and Western Blot of FSNV. Lane 1: Molecular weight marker; Lane 2: Semi-purified FSNV: (a) Capsid protein, (b) Polymerase-associated protein, (c) Movement protein 1, (d) Movement protein 2; Lane 3: FSNV purified by ultracentrifugation; Lane 4: Western Blot of FSNV purified by ultracentrifugation using anti-FNSV IgY. *Additional band corresponding with viral protein with post-translational changes. + RNA-directed RNA polymerase. This figure is a composition in which, Lines 1 and 2 are from the same gel while Line 3 and Line 4 are each one from different gels. 


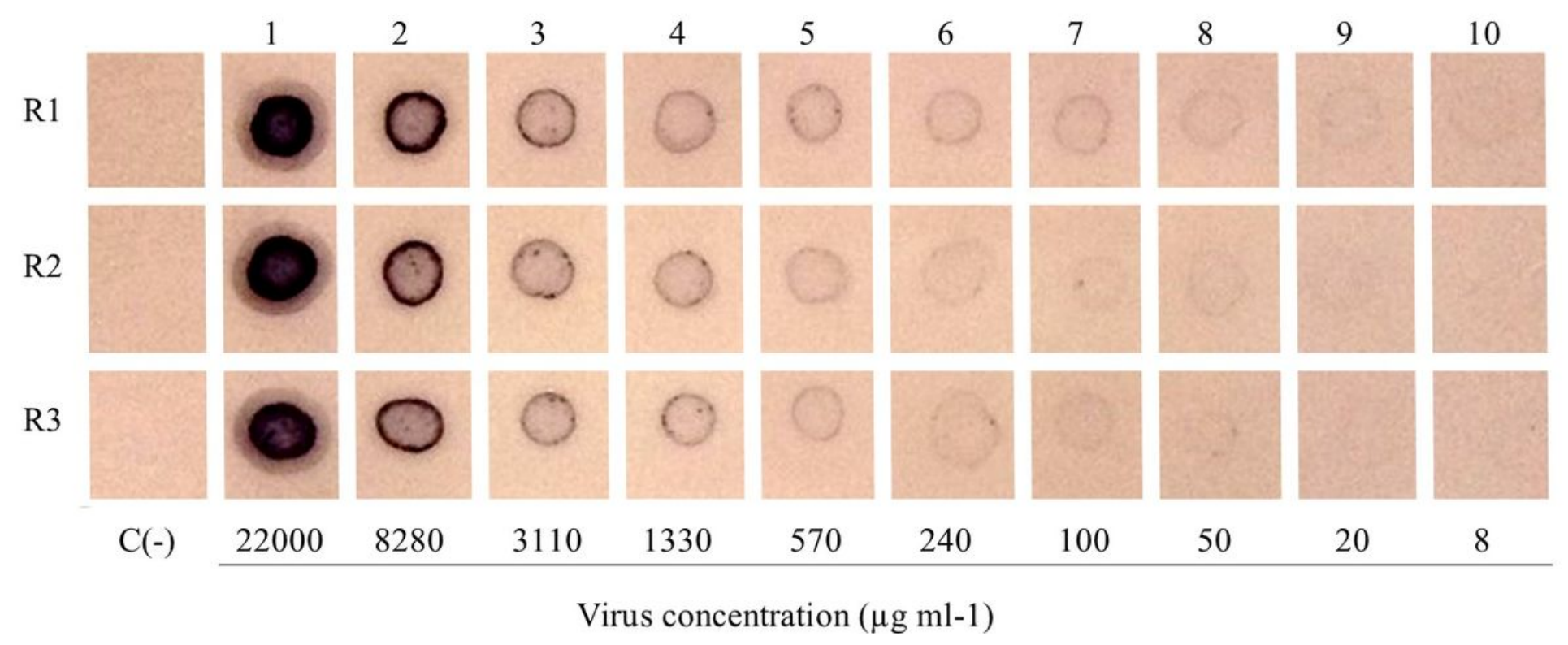

\section{Figure 3}

DBIA detection sensitivity of anti-FNSV IgY. C (-). Negative control (ultrapure water). Columns 1-10: Different concentrations of antigen (purified "Macana" virus). Rows correspond to replicates. This figure corresponds to the same nitrocellulose membrane. 

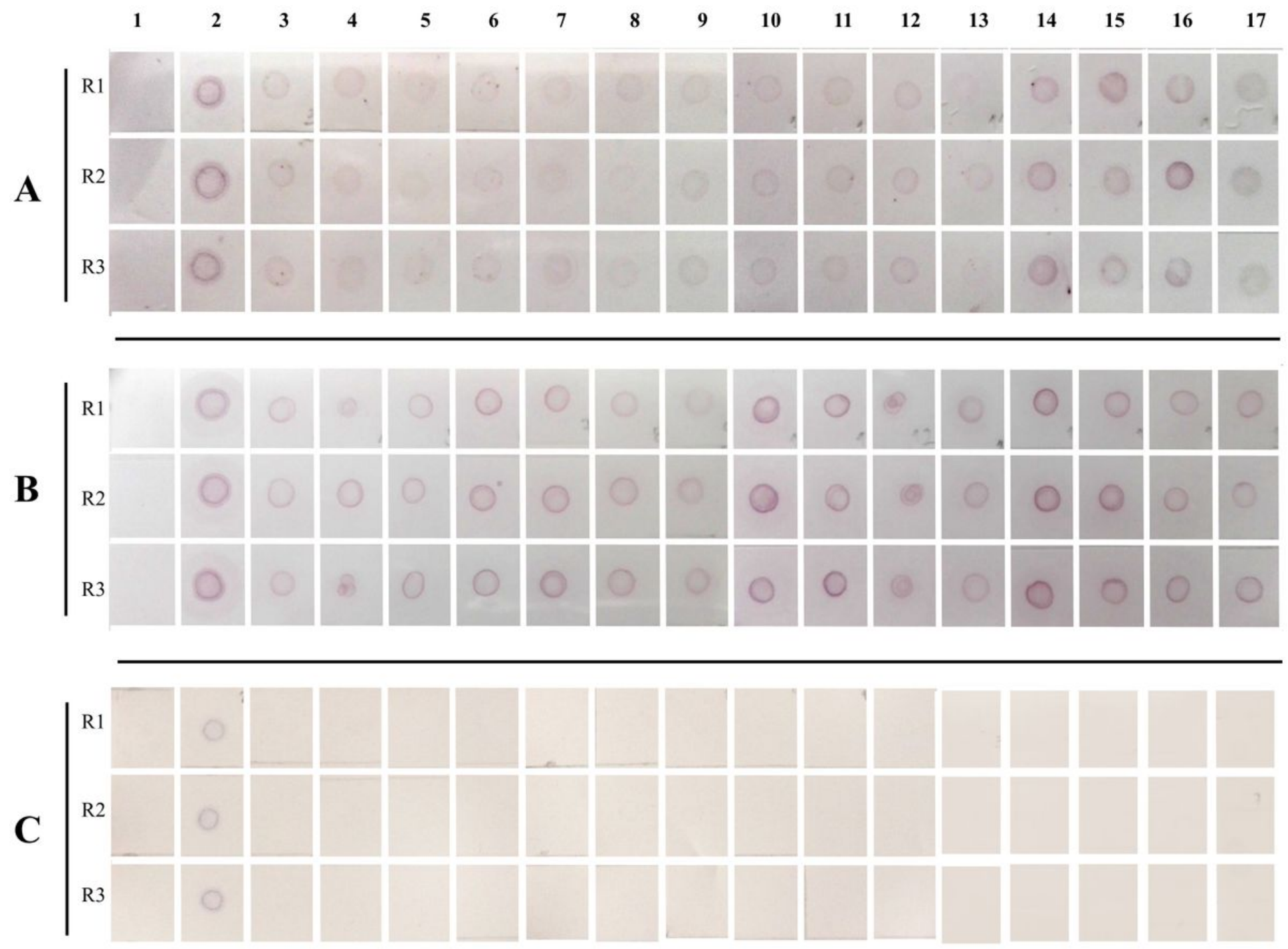

\section{Figure 4}

DBIA test for detecting immunoreactivity of anti-FNSV IgY against "Macana” virus in vegetal samples. Leaf and root samples from the same "Macana" diseased plant were analysed: A) Leaf samples and B) Root samples. C) Leaf samples from healthy plants. Column 1: Negative control (ultra-pure water); Column 2: positive control (semi-purified virus); columns 3-17: leaf and root samples. The rows correspond to replicates. Figures $4 \mathrm{~A}, 4 \mathrm{~B}$ and $4 \mathrm{C}$ correspond to different nitrocellulose membranes. 


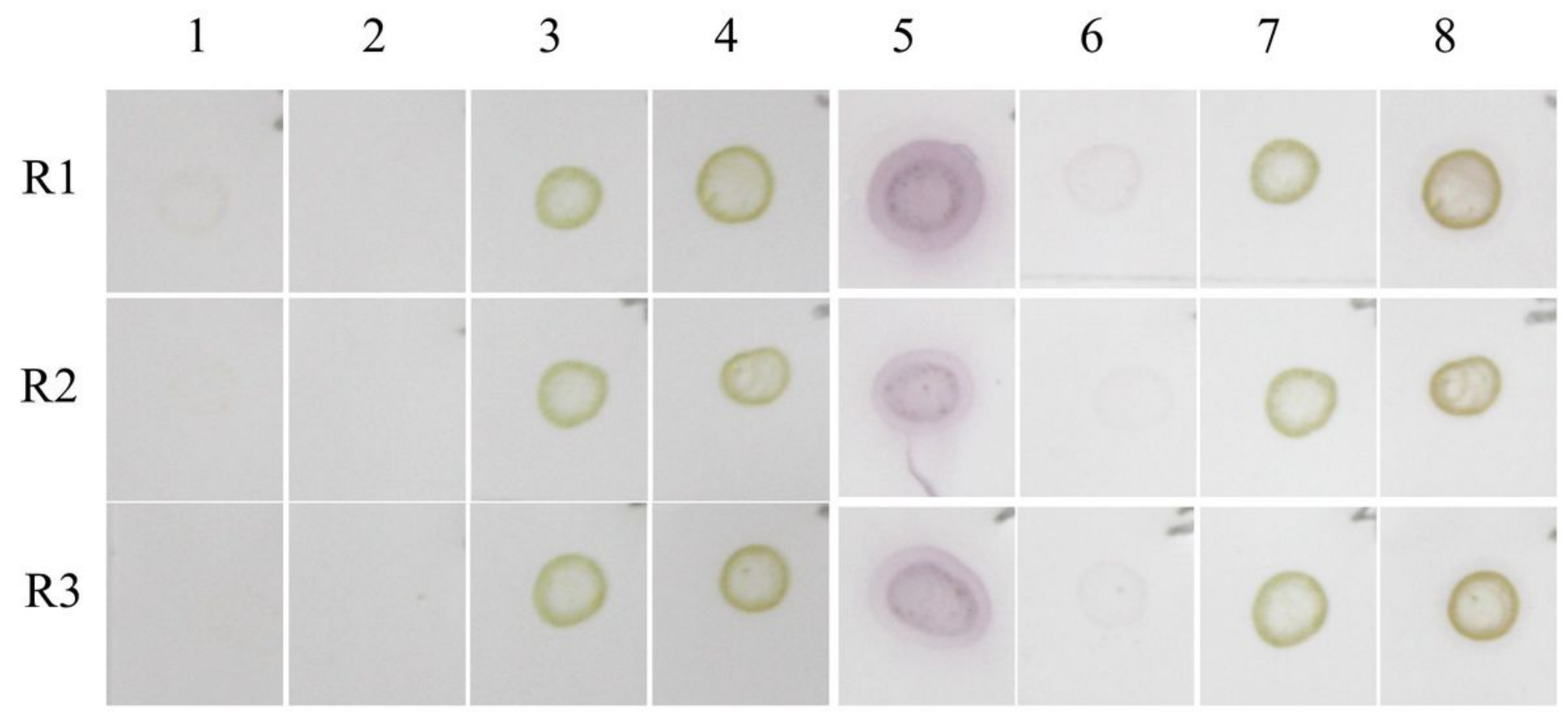

Before alkaline phosphatase chromogen solution After alkaline phosphatase chromogen solution

Figure 5

DBIA to assess specificity of anti-FNSV IgY against "Macana" virus in vegetal samples. Columns 1 and 5: purified virus; Columns 2 and 6: semi-purified FNSV; Columns 3 and 7: macerate of rose leaf (Rosa sp.) with symptoms of viral infection consistent with RMVc complex; Columns 4 and 8: macerate of potato leaf (Solanum tuberosum) infected with PYVV virus. Rows correspond to replicates. This figure corresponds to the same nitrocellulose membrane.

A

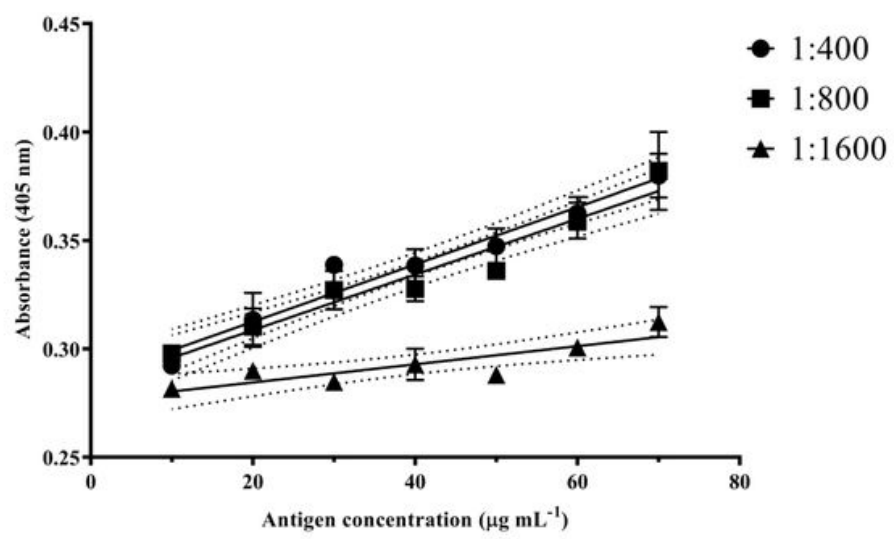

B

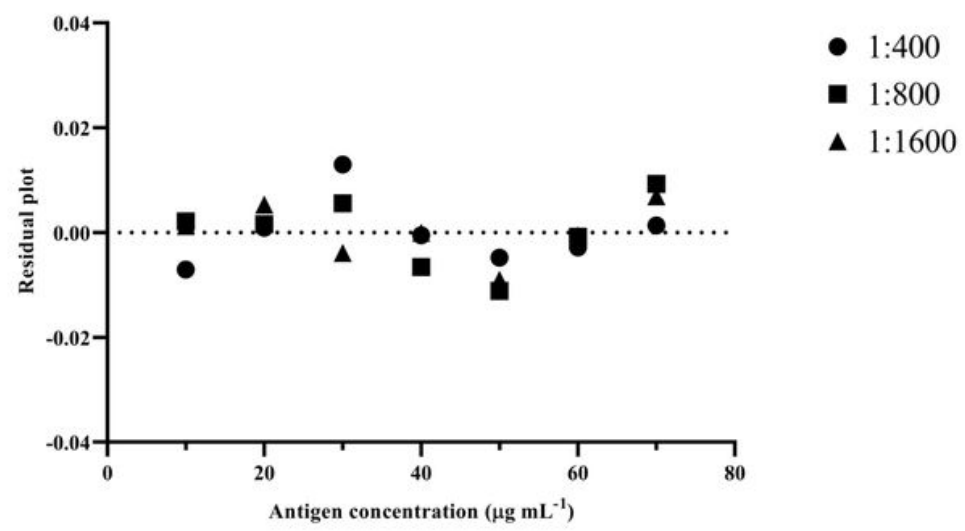

Figure 6

A. Absorbance values obtained with different concentrations of the pure virus in the ELISA test to determine the IgY antibody titer. B. Residual plot. 